NBSIR 73-192

Acoustical Evaluation of a Single Family Detached Honeycomb Panel Housing System Constructed on an Operation Breakthrough Prototype Site

Thomas L. Quindry

Applied Acoustics and Illumination Section

Center for Building Technology (Building Research Division)

Institute for Applied Technology

National Bureau of Standards

Washington, D. C. 20234

April 1973

Final Report

Prepared for

Office of Research and Technology

Department of Housing and Urban Development

Washington, D. C. 20410 
NBSIR 73-192

\section{ACOUSTICAL EVALUATION OF A SINGLE FAMILY DETACHED HONEYCOMB PANEL HOUSING SYSTEM CONSTRUCTED ON AN OPERATION BREAKTHROUGH PROTOTYPE SITE}

Thomas L. Quindry

Applied Acoustics and Illumination Section

Center for Building Technology (Building Research Division)

Institute for Applied Technology

$N$ ational Bureau of Standards

Washington, D. C. 20234

April 1973

Final Report

Prepared for

Office of Research and Technology

Department of Housing and Urban Development

Washington, D. C. 20410

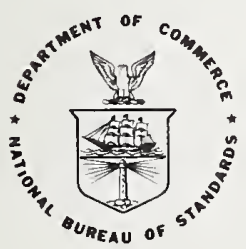

U. S. DEPARTMENT OF COMMERCE, Frederick B. Dent, Secretary NATIONAL BUREAU OF STANDARDS, Richard W. Roberts, Director 
ACOUSTICAL EVALUATION OF A SINGLE FAMILY DETACHED

HONEYCOMB PANEL HOUSING SYSTEM CONSTRUCTED

ON AN OPERATION BREAKTHROUGH PROTOTYPE, SITE

by

\author{
Thomas L. Quindry \\ Applied Acoustics and Illumination Section \\ Building Research Division
}

\title{
ABSTRACT
}

The acoustical performance of a single family detached honeycomb panel housing system was tested on an Operation BREAKTHROUGH prototype site.

Test results are given concerning the noise isolation of intradwelling walls and the noise levels within living units.

Key Words: Acoustics; noise criterion curve; noise isolation class; Operation BREAKTHROUGH 
TABLE OF CONTENTS

PAGE

Abstract . . . . . . . . . . . . . . . . . . . i

1. Introduction . . . . . . . . . . . . . . . . 1

2. Objective. . . . . . . . . . . . . . . . . . 1

3. Test Procedure . . . . . . . . . . . . . . . 2

4. Description of Housing System. . . . . . . . . . . 4

5. Test Results . . . . . . . . . . . . . . 5

5.1 Noise Isolation of Intra-Dwelling Walls . . . . . . 5

5.2 Noise Level Within Living Unit. . . . . . . . . . 6

6. Field Tests on a Similar System. . . . . . . . . . 6

7. Discussion . . . . . . . . . . . . . . . 7

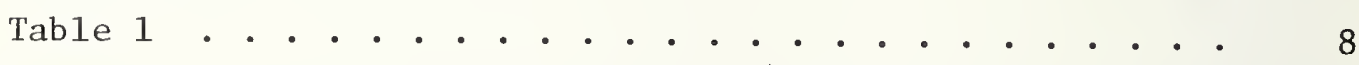

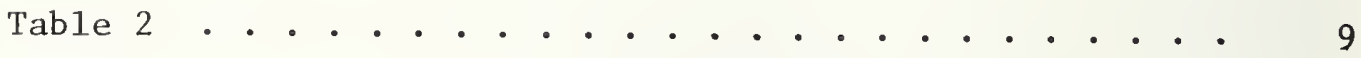

Table 3 . . . . . . . . . . . . . . . . 10 


\section{INTRODUCTION}

Drawings and specifications for the housing systems being demonstrated as a part of Operation BREAKTHROUGH were reviewed in order to determine the acoustical performance of the dwelling units. Any potential deficiencies in acoustic performance were noted such that appropriate action could be taken prior to manufacture and site installation of the housing units.

Poor workmanship, however, can negate even the best planned acoustical improvement. The many unknowns associated with workmanship, possible damage to the housing modules during shipment, assembly of the housing modules on the building site, and even the modular concept of construction typical of many of the Operation BREAKTHROUGH housing systems, emphasized the importance of performance testing.

More builders than ever before are now at least aware that acoustic quality in buildings is becoming an essential consumer requirement. A great deal of information can ultimately be drawn from the acoustical performance testing of Operation BREAKTHROUGH housing.

\section{OBJECTIVE}

The objective of this work was to obtain information regarding interior noise levels and the intra-dwelling noise isolation provided by this prototype housing system constructed within the Operation BREAKTHROUGH Program on one of the prototype sites, and to provide this information as a data base for possible comparison with the acoustical performance of conventional housing. 


\section{TEST PROCEDURE}

All tests were performed in accordance with the methods outlined in the appropriate standards. The pertinent tests include:

Appendix Al of ASTM E 336-71, "Recommended Practice for the Measurement of Airborne Sound Insulation in Buildings."

ASTM E413-70T, "Tentative Classification for Determination of Sound Transmission Class." (This test method is used for the determination of Nolse Isolation Class.)

ASTM C 423-66, "Standard Method of Test for Sound Absorption of Acoustical Materials in Reverberation Rooms," Section 9.1 , for measurement of decay rate procedure.

ANSI S1.2-1962, "ANSI Standard Method for the Physical Measurement of Sound."

A11 measurements were carried out using the NBS Mobile Acoustical Laboratory (1). A complete list of the equipment utilized for these measurements is given in Table 1.

Airborne noise reduction was measured using 1/3-octave bands of pink random noise ${ }^{(2)}$ to excite the speaker systems. A multiplex system which scanned the outputs of the microphones was used for simultaneous spatial averaging in both the source and receiving rooms. The output of the multiplexer was passed through a 1/3-octave band-pass filter set and then to the measuring system.

(1) Winzer, George E., National Bureau of Standards Mobile Acoustical Laboratory, Sound and Vibration, May 1970.

(2) Pink random noise is a quantity (e.g., sound pressure) whose amplitude probability is a normal (Gaussian) distribution curve and whose frequency spectrum slopes at minus $3 \mathrm{~dB}$ per octave. 
A total of five microphones, in a modified spherical array as shown in Figure 1, was used in all rooms. The distribution of sound in the source room was improved by the addition of an $8 \mathrm{ft}$. $11 \mathrm{ft}$ honeycomb reflecting panel placed at an angle such that its top edge was resting across the entire wall that was opposite the primary test wall.

Temporal averages of sound pressure levels were obtained using a true root-mean-square voltmeter in order to obtain less statistical error in sound pressure levels than can be obtained with the graphic leve1 recorder recommended in ASTM E 336-71. A differential amplifier was used with two true r.m.s. voltmeters to obtain the differences in the r.m.s. sound pressure levels of the random noise between the source and the receiving room. Airborne noise reduction determination averaging time of 100 seconds for tests at frequencies from 125 through $400 \mathrm{~Hz}$ and 30 seconds for tests at frequencies from 500 through $4000 \mathrm{~Hz}$ were used in order to achieve a statistical error (due to temporal averaging) of less than $\pm 0.4 \mathrm{~dB}$ (at a confidence level of 95 percent).

The uncertainty in measured sound pressure levels, due to random and systematic uncertainties associated with the overall data acquistition system, is estimated (95 percent confidence leve1) to be less than $\pm 1 \mathrm{~dB}$ for relative sound pressure levels (measured to determine airborne noise reductions) over a range of band-center frequencies from 100 to $4000 \mathrm{~Hz}$. ASTM E 336-71 specifies that for suitable accuracy in determining the average sound pressure levels in the source and receiving rooms, the 
rooms shall be large enough that there are at least 10 normal modes per measurement bandwidth. The lower limit of frequency for which this would occur using $1 / 3$ octave bands was: $200 \mathrm{~Hz}$ for the bathroom, $155 \mathrm{~Hz}$ for the bedroom and $112 \mathrm{~Hz}$ for the living rooms.

For the airborne noise reduction measurements the background noise in the receiving room was at least $10 \mathrm{~dB}$ below the transmitted signal. The equivalent sound absorption of the receiving rooms was determined by the reverberation decay method described in ASTM C 423-66. Measurements of noise levels of certain mechanical equipment were carried out for comparison with the Noise Criterion (NC) contours (3). An octave band-pass filter set and graphic level recorder were used for these measurements. The background noise in the receiving room was at least $10 \mathrm{~dB}$ below the sound pressure level of the equipment being measured.

During the field measurements the temperature was nominally $65^{\circ} \mathrm{F}$ and the relative humidity $50 \%$.

\section{DESCRIPTION OF HOUSING SYSTEM}

The housing system which was tested is classified as a single family detached housing system. It was a panelized system consisting of a three bedroom/bath module, a living room/kitchen module, and a family room/bedroom/bath module. The three modules were joined by interconnecting hallways to form a single story dwelling. The floor plan of the three bedroom/bath module which was tested is shown in Figure 1 . The

(3) Schultz, T. J., Noise Criterion Curves for use with the USASI Preferred Frequencies," J. Acoust. Soc. Am. 43, 637-638 (1968). 
living units were unfurnished except for kitchen equipment. The living room, hallways and bedrooms were carpeted. The kitchen and bathroom floor areas were covered with vinyl asbestos tile.

The modules were erected over a shallow crawl space and were supported by a steel grade beam at the perimeter which housed the supply and return ducts as well as electrical raceways. The interior wall is composed of 4'4" $\times 8^{\prime} 31 / 4^{\prime \prime}$ panels, nominally 2 inches thick, with paper honeycomb cores and primed galvanized sheet steel faces. The exterior wall is similar to the interior wall except the honeycomb panels are nominally 3 inches thick with foamed polyurethane insulation projecting into the honeycomb core approximately 1 1/2 inches on the exterior side. The exterior wall panels are joined on the vertical sides by wood tongue and groove joints.

The floor system is 3-3/8 inch honeycomb with 3/8-inch plywood face on the top surface and a galvanized sheet steel face on the bottom surface. The roof is of a construction similar to the exterior walls except that the polyurethane insulation projects into the honeycomb core $21 / 4$ inches. Cross-sections of the wall, ceiling, and floor constructions are shown in Figure 2.

\section{TEST RESULTS}

\subsection{Noise Isolation of Intra-Dwelling Wa11s}

Each measured noise reduction was normalized to a reference receiving room absorption, $A_{0}$, of $10 \mathrm{~m}^{2}$ (100 $\mathrm{ft}^{2}$ ) according to the following equation: 


$$
N R_{11}=N R-\left(\begin{array}{lll}
10 & \log _{10} \Lambda_{0}
\end{array}\right)
$$

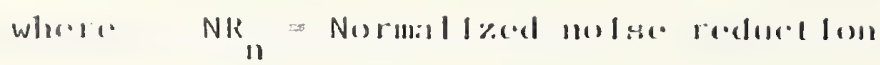

$$
\text { NR = Noise reduction before normalization }
$$

$A=$ Total sound absorption of the receiving space.

The results of measurements of the normalized noise reduction between horizontally adjacent bedrooms and bedroom to bathroom are shown as a function of frequency in Figures 3 and 4. The three-segmented solid line represents the Noise Isolation Class (NIC) contour fitted to these data according to the specified ASTM procedure. The arrow points to the normalized NIC value. The normalized NIC values are given in Table 2 .

\subsection{Noise Leve1 Within Living Unit}

The noise leve1 in bedroom $\#_{1}$ with the heating system in operation is given in Figure 5 along with the Noise Criterion (NC) contours. The measured NC value is given in Table 2 .

\section{FIELD TESTS ON A SIMILAR SYSTEM}

An engineering model was constructed according to the Operation BREAKTHROUGH system drawings inside an assembly plant prior to the erection of the Operation BREAKTHROUGH units. This unit was tested before the availability of the Operation BREAKTHROUGH units in order to obtain information regarding the system. These tests provided much insight into the intra-dwelling noise isolation provided by a metal panel, honeycomb core construction system, particularly since the floor plan layout was such that buffer zones were created between rooms either by closets or hallways. A comparison of data is given in Table 3 . An 
estimate of the effectiveness of the exterior shell of the engineering model in attenuating exterior noise was measured. Since the engineering model was located in a factory the recommended procedures for measurement of the exterior shell attenuation could not be followed. The results, however, did give some indication of the expected performance of the exterior she11.

For the purposes of estimating the Noise Criterion contour which one might expect in an urban area, available noise data for an Operation BREAKTHROUGH prototype site were compared with the noise reduction obtained with the engineering model. It was estimated that from exterior noise sources the noise level would be from NC 50 to NC 65.

As a result of these findings, the joining configuration of the exterior panels, which had been pinpointed as the cause for poor performance, was re-designed by the producer. Inspection of the prototype units on the BREAKTHROUGH site indicated that the exterior shell attenuation was improved. Weather conditions prohibited a field test of the exterior shell.

\section{DISCUSSION}

The acoustical performance of this housing system was improved by careful design and evaluation of the system in conjunction with the acoustical criteria of Operation BREAKTHROUGH. Major changes which improved the acoustical performance of the dwelling unit included modification of the exterior shell and inclusion of a quieter heating unit. 
Table 1

Instrumentation*

1. Brüe1 \& Kjaer 1402 Random Noise Generator

2. (3) Brüel \& Kjaer Models 1612, 5004 Band-Pass Filter Sets

3. JBL Speaker Systems

4. (2) Brüel \& Kjaer 2606 Measuring Amplifier

5. (2) Brüel \& Kjaer 215 RMS Converter \& Log Amplifier

6. (2) Brüel \& Kjaer 221 Microphone Energizer - Multiplixer

7. Brüel \& Kjaer 2305 Graphic Level Recorder

8. (12) Brüe1 \& Kjaer 4132 Condensor Microphones

9. (12) Brüel \& Kjaer 2619 FET Preamplifier

10. (2) Brüe1 \& Kjaer 4220 Pistonphone

11. NBS Differential Amplifier

12. NBS Reverberation Time Measuring System

13. HP 5325 A Counter

*Commerical instruments are identified in this report in order to adequately specify the experimental procedure. In no case does such identification imply recommendation or endorsement by the National Bureau of Standards, nor does it imply that the equipment identified is necessarily the best available for the purpose. 
Table 2

The Measured Nolse Isolat I on Characterfst lcs of the Hownling system

\begin{tabular}{|c|c|c|c|}
\hline Partition & $\begin{array}{c}\text { Source Room } \\
\text { Unit } \\
\end{array}$ & $\begin{array}{c}\text { Recelve Room } \\
\text { Unit }\end{array}$ & $\begin{array}{l}\text { Normalized } \\
\text { NIC }\end{array}$ \\
\hline $\begin{array}{l}\text { Intra-dwelling } \\
\text { Wall }\end{array}$ & $\begin{array}{l}\text { Bathroom } \\
\text { 16-SFD/03-02 }\end{array}$ & $\begin{array}{l}\text { Master Bedroom } \\
16-\text { SFD/03-02 }\end{array}$ & 33 \\
\hline $\begin{array}{l}\text { Intra-dwelling } \\
\text { Wall }\end{array}$ & $\begin{array}{l}\text { Back Bedroom } \\
16 / \text { S FD/03-02 }\end{array}$ & $\begin{array}{l}\text { Middle Bedroom } \\
\text { 16-SFD/03-02 }\end{array}$ & 29 \\
\hline
\end{tabular}

Table 2 (cont.)

\begin{tabular}{|c|c|c|}
\multicolumn{2}{c}{$\begin{array}{c}\text { Receive Room } \\
\text { Unit }\end{array}$} & \multicolumn{1}{c}{ NC } \\
\hline Heater on & $\begin{array}{l}\text { Master Bedroom } \\
16-S F D / 03-02\end{array}$ & $<40$ \\
& & \\
\hline
\end{tabular}


Table 3

The Measured Noise Characteristics of the BREAKTHRnUGH Housing System Compared with the Measured Noise Characteristics of the Engineering Mode1

\begin{tabular}{|c|c|c|c|c|}
\hline \multirow[b]{2}{*}{ Partition } & \multirow[b]{2}{*}{$\begin{array}{c}\text { Source Room } \\
\text { Unit } \\
\end{array}$} & \multirow[b]{2}{*}{$\begin{array}{c}\text { Receive Room } \\
\text { Unit }\end{array}$} & \multicolumn{2}{|c|}{ Normalized NIC } \\
\hline & & & $\begin{array}{l}\text { BREAK- } \\
\text { THROUGH }\end{array}$ & $\begin{array}{l}\text { Engi- } \\
\text { neering } \\
\text { Model }\end{array}$ \\
\hline $\begin{array}{l}\text { Intra-dwelling } \\
\text { Wa11 }\end{array}$ & Bathroom & $\begin{array}{l}\text { Master } \\
\text { Bedroom }\end{array}$ & 33 & 33 \\
\hline $\begin{array}{l}\text { Intra-dwelling } \\
\text { Wa11 }\end{array}$ & $\begin{array}{l}\text { Back } \\
\text { Bedroom }\end{array}$ & $\begin{array}{l}\text { Middle } \\
\text { Bedroom }\end{array}$ & 29 & 30 \\
\hline
\end{tabular}

Table 3 (cont.)

\begin{tabular}{|c|c|c|c|}
\hline & $\begin{array}{c}\text { Receive Room } \\
\text { Unit }\end{array}$ & BREAKTHROUGH & $\begin{array}{c}\text { Engineering } \\
\text { Mode1 }\end{array}$ \\
\cline { 2 - 4 } Equipment & $\begin{array}{c}\text { Master } \\
\text { Bedroom }\end{array}$ & $<40$ & $<55$ \\
\hline
\end{tabular}




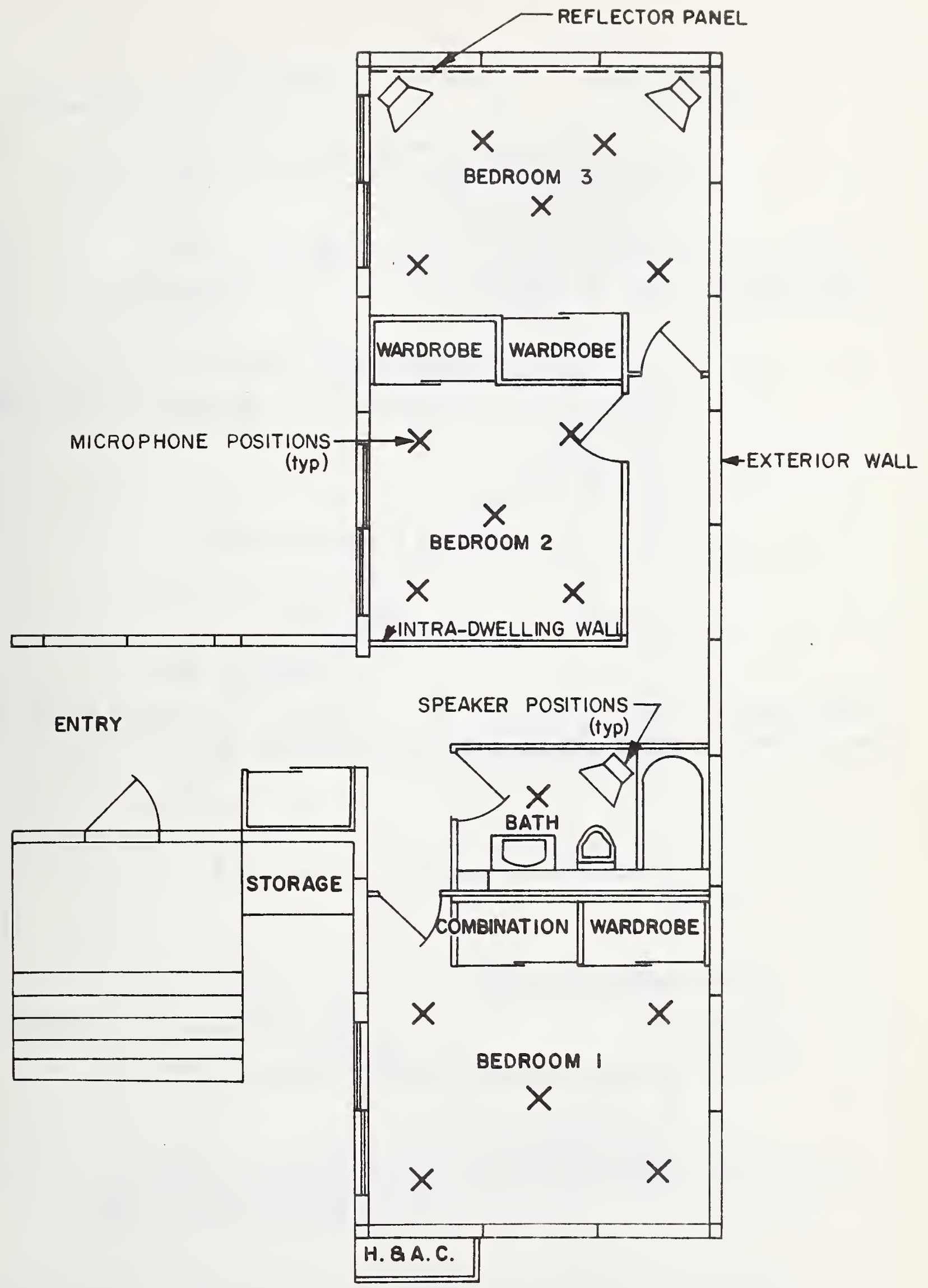

Figure i. Floor plan showing microphone and speaker positions. 


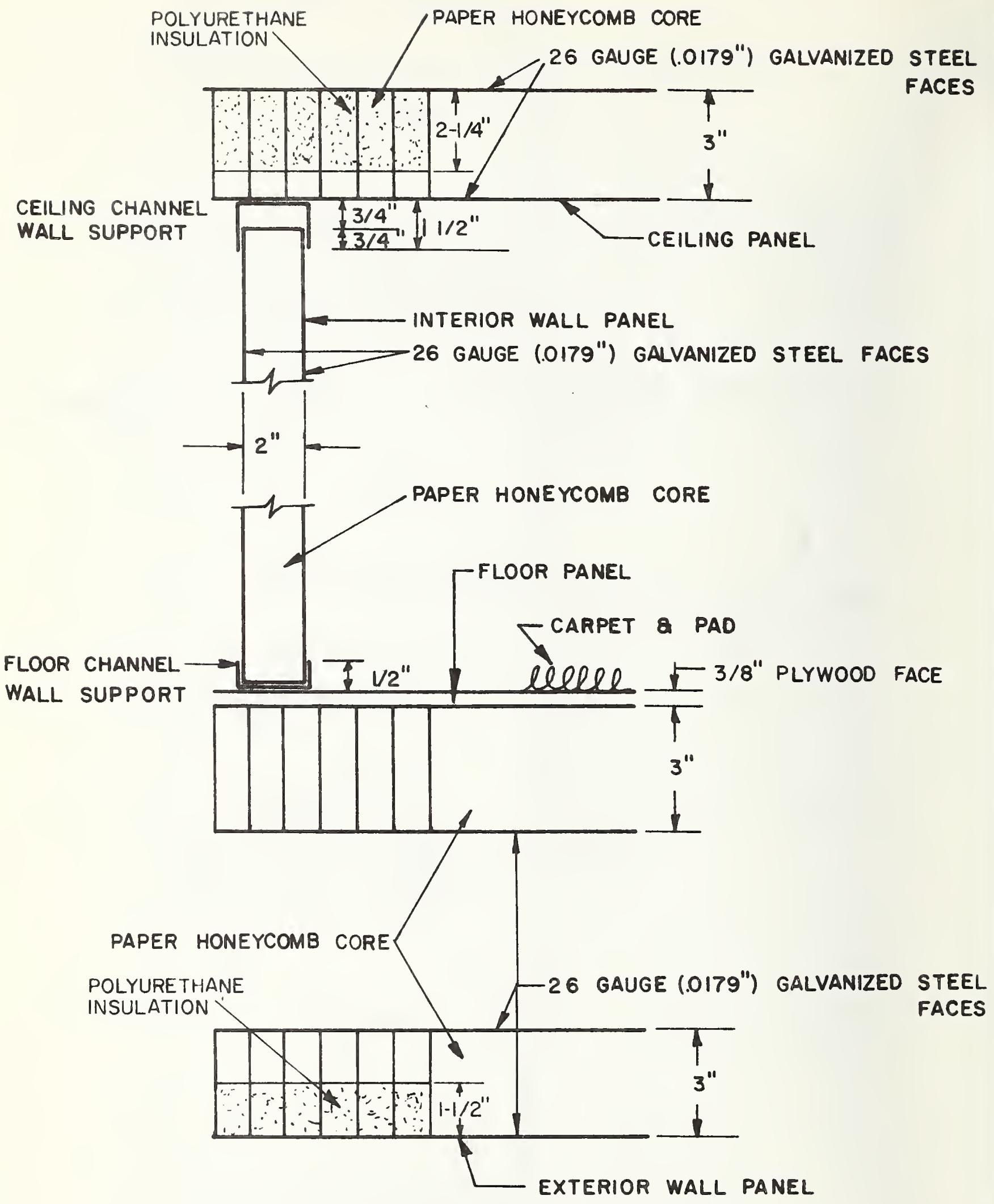

Figure 2. Cross sections of wall, ceiling, and floor constructions. 


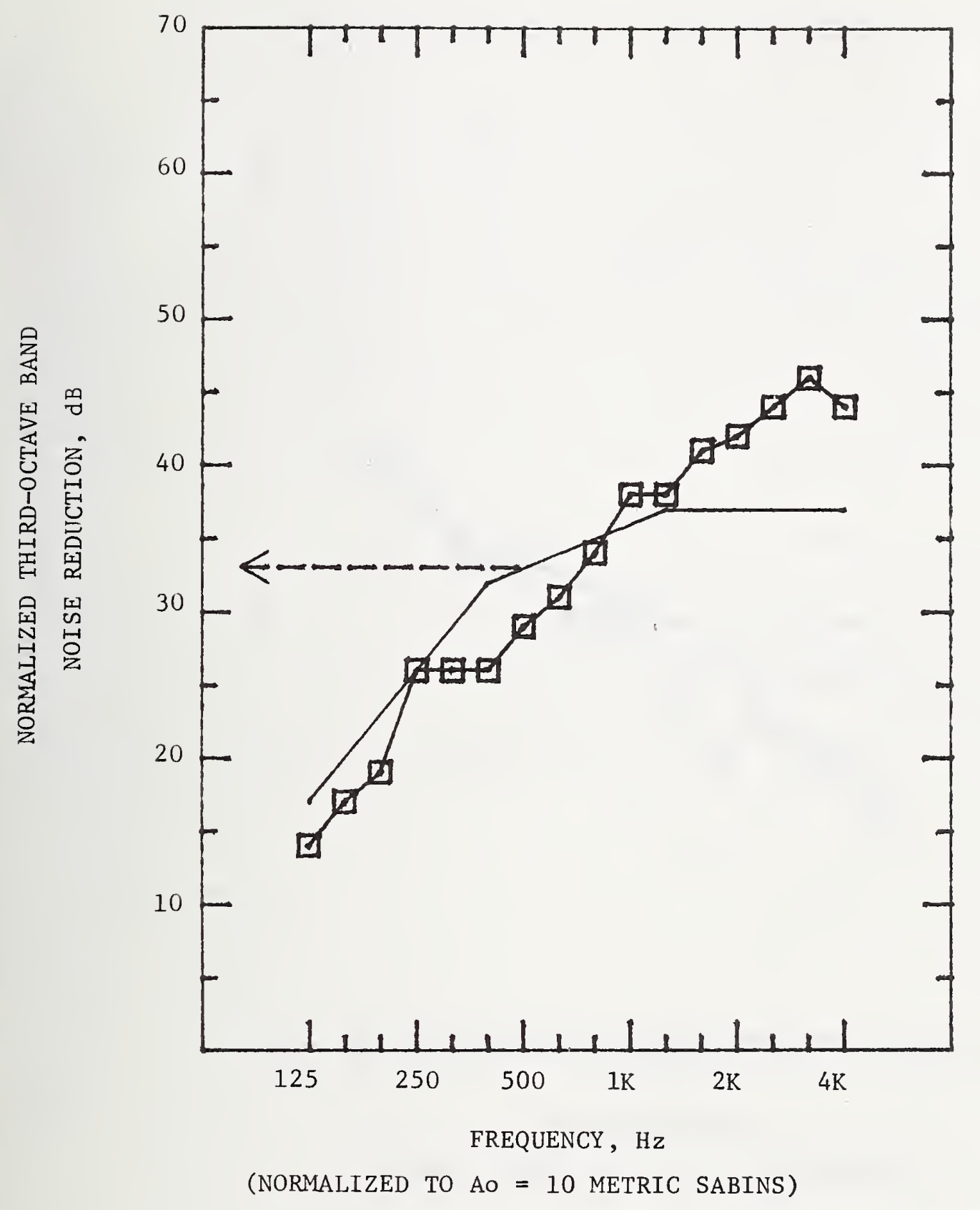

Figure 3. Normalized 1/3-Octave Band Noise Reduction Between the Bathroom and Bedroom No. I separated by an Intra-Dwelling Wall. Unit 16-SFD/03-02 (NIC - 33). 


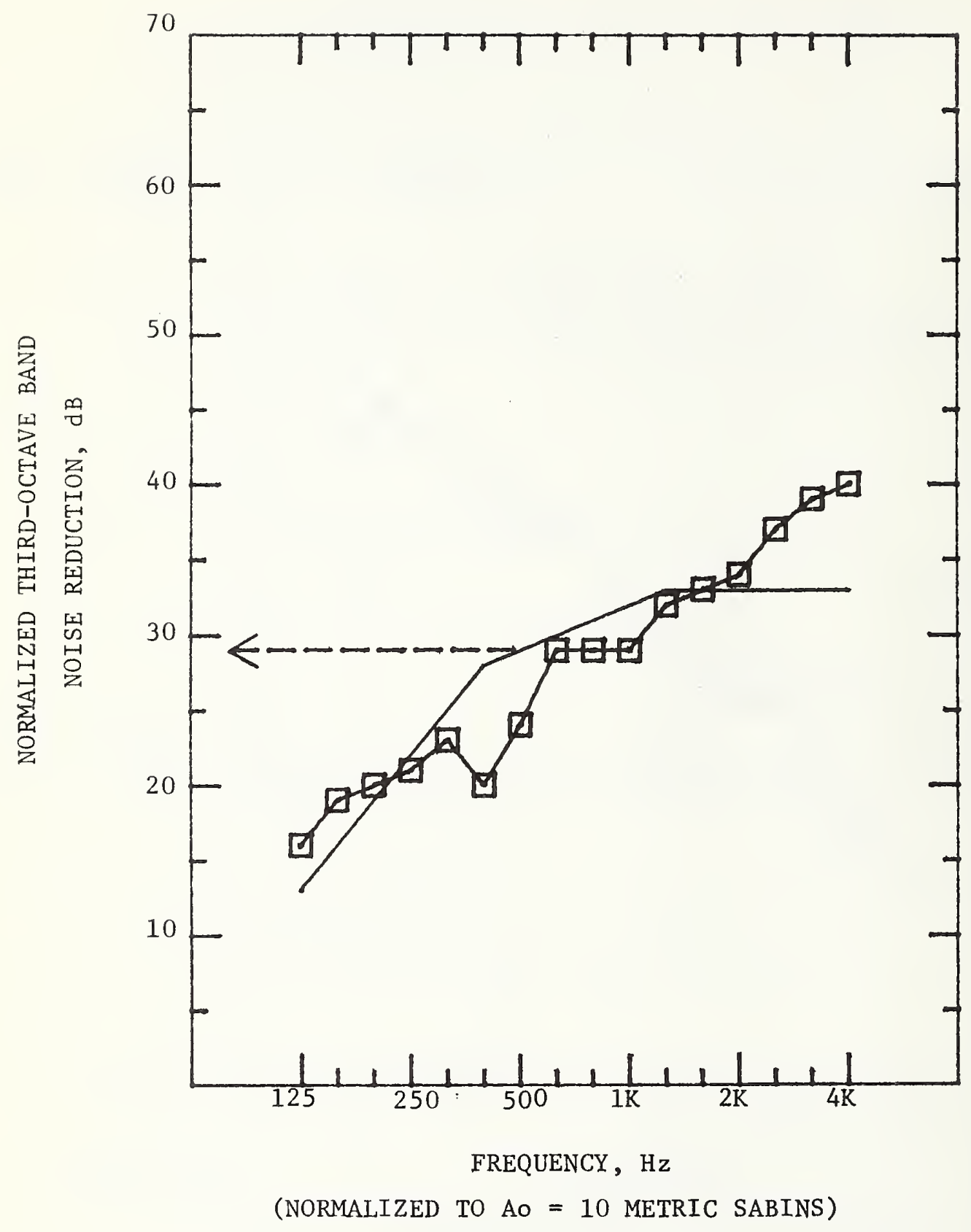

Figure 4. Normalized 1/3-Octave Band Noise Reduction Between Bedroom No. 2 and Bedroom No. 3 separated by an IntraDwelling Wall. Unit 16-SFD/03-02 (NIC - 29). 


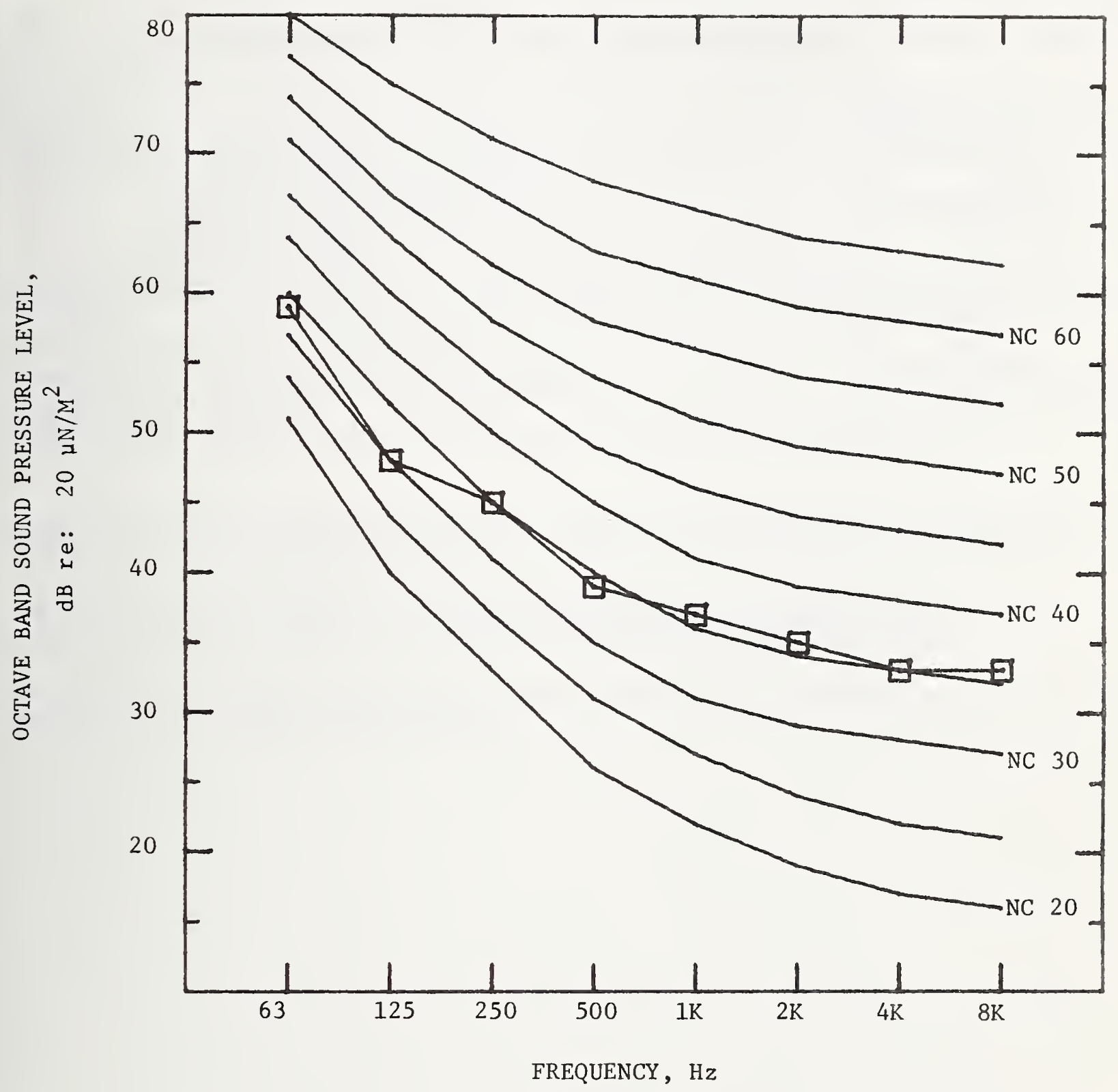

Figure 5. Octave Band Sound Pressure Level in Bedroom No. 1. Unit 16-SFD/03-02 with the Heating system Running. $(<N C-40)$. 

FORM NBS-114A $11-711$

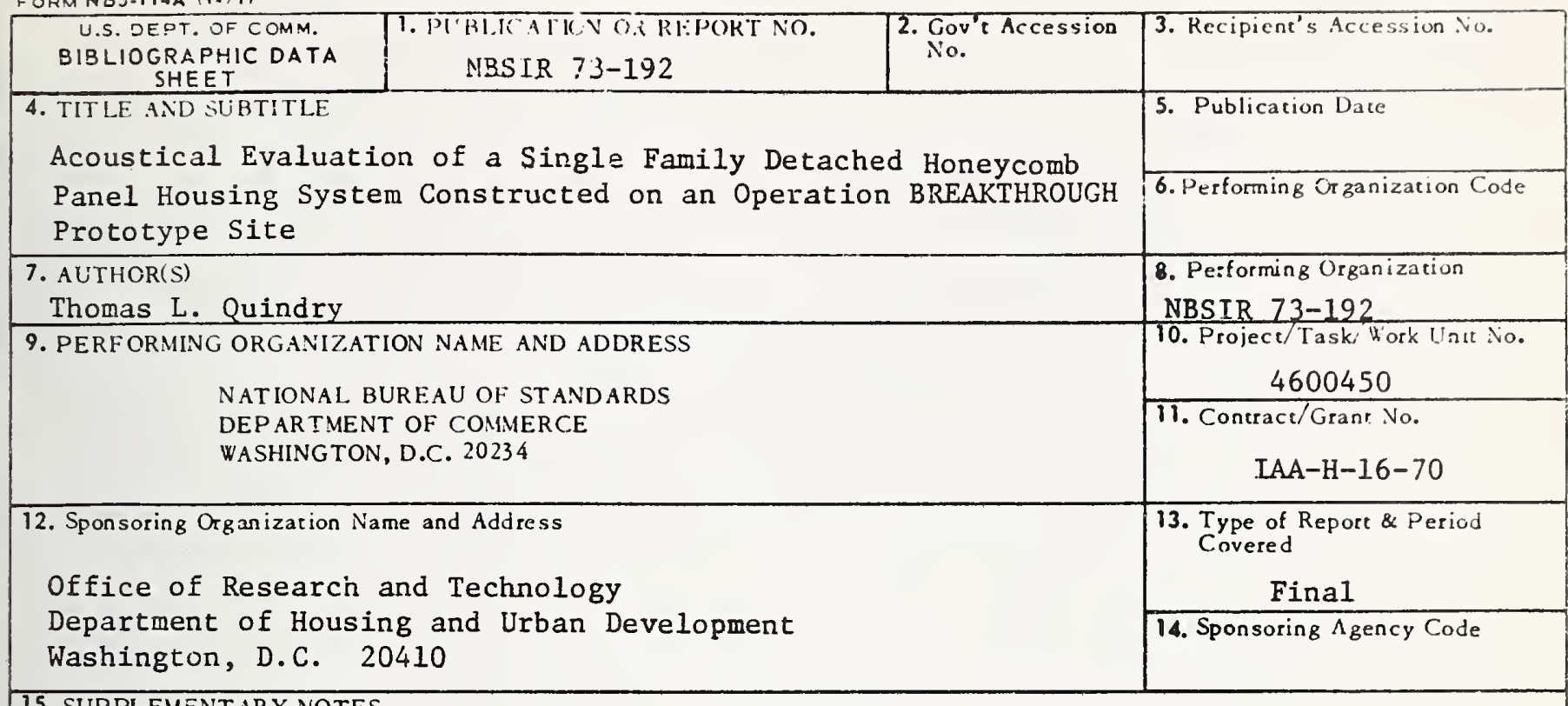

15. SUP PLEMENTARY NOTES

16. ABSTRACT (A 200-word or less factual summary of most significant information. If document includes a significant bibliography or literature survey, mention it here.)

The acoustical performance of a single family detached honeycomb panel housing system was tested on an Operation BREAKTHROUGH prototype site.

Test results are given concerning the noise isolation of intradwelling walls and the noise levels within living units.

17. KEY WORDS (Alphabctical order, separated by semicolons)

Acoustics; noise criterion curves; noise isolation class; Operation BREAKTHROUGH

\begin{tabular}{|c|c|c|}
\hline $\begin{array}{l}\text { 18. AVAILA BILITY STATEMENT } \\
\bigotimes \text { UNLIMITED. }\end{array}$ & $\begin{array}{l}\text { 19. SECURITY CLASS } \\
\text { (THIS REPORT) } \\
\text { UNCL ASSIFIED }\end{array}$ & 21. NO. OF PACES \\
\hline $\begin{array}{l}\text { FOR OFFICIAL DIST RIBUTION. DO NOT RELEASE } \\
\text { TO NTIS. }\end{array}$ & $\begin{array}{l}\text { 20. SECURITY CLASS } \\
\text { (THIS PAGE) } \\
\text { UNCI.ASSIFIED }\end{array}$ & 22. Price \\
\hline
\end{tabular}




